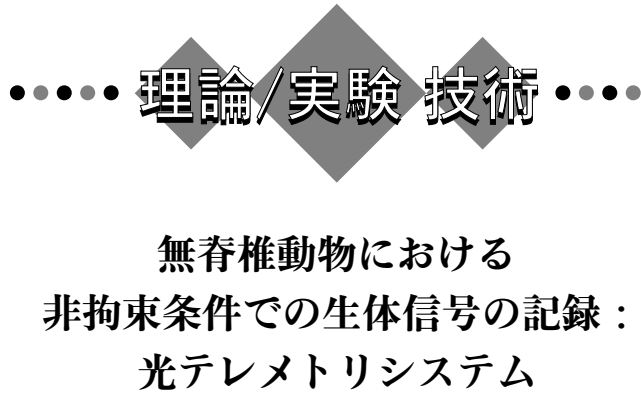

北海道大学大学院理学研究科生物科学専攻

濱 徳行, 高烟雅一

北海道大学電子科学研究所

土田義和

\section{1. はじめに}

動物の行動は単純に感覚情報にもとづく反射運動で はなく,動物がどのような行動を遂行しているのか, ま たは遂行しようとしているのか, といった行動文脈に 依存して修飾される ${ }^{1-5)}$. 我々はこれまで, ザリガニの 姿勢制御運動に着目し, おもにガラス管微小電極を用 いた細胞内記録法によって, この神経機構における行 動文脈依存的な修飾機序の解析を行ってきた ${ }^{6,7)}$. しか しながら，細胞内記録法を用いると，動物を何らかの 形で固定する必要があり, 自然条件下で見られるよう な多様な行動はほとんど見られなくなるため, より自 然な状態における神経活動の記録を行う必要がある.

自由行動下における神経活動などを記録・解析する ためには，無線記録法が広く用いられている ${ }^{8-111}$. 無 線記録では, 送信器側で生体信号をなんらかの手法に より電波や超音波などに乗せ (変調), 受信器側でそれ を復調する. 電波を用いた無線記録では周波数変調 (FM 変調) が広く用いられている. FM変調は生体信号を電 圧制御発振器の制御電圧として加えることによって得 られる. 電圧制御発信器の入手が比較的簡単であるた め, 広く用いられている. しかしながら, 電波は水中, 特に伝導性が高い海水中では減衰が大きい(2)-14). さら に, これまで開発されてきた送信器は多くが筋肉の活 動電位（筋電図）や脳波などの遅い信号の記録を目的 としており ${ }^{10), 11), 15)}$, 神経の活動電位のような速い信号 の記録はほとんどなされていなかった。

今回我々は, 光を用いた無線記録システムを開発し
た．光も電波と同様，水中で減衰するが，水の光吸収 係数は比較的低いため ${ }^{16}$, 淡水中だけでなく海水中で も安定した記録が可能である. 加えて, このシステム はすべて市販の電子部品で構成されているため導入が 容易である. 本システムの回路図の詳細についてはオ ンライン版に添付した supplemental figures を参照され たい.

\section{2. 光テレメトリシステムの概要}

本光テレメトリシステムで用いられている変調方 式は, 信号の振幅をパルスの間隔に変換するための pulse duration modulation (PDM)/ pulse interval modulation （PIM）法を若干修正したものである. 各チャネルの信 号は, PDM変調された後, PIM信号に変換され, 赤外 発光ダイオード（IRLED）を駆動する（Fig. 1）. PIM 信号を用いることで, 発光ダイオード（IRLED）の駆 動時間を短縮し, 消費電力を節約している. 赤外光パ ルスとして無線発信された信号をPINフォトダイオー ドで受信した後, 逆の手順を経てアナログ信号へと復 調する (Fig. 1).

$\mathrm{PDM}$ 変調は矩形波を発生する単安定マルチバイブ レータ（以下モノマルチ）の出力パルス幅を設定する 外付 $\mathrm{CR}$ 充電回路に信号電圧を加重して, 出力パルス幅 を変化させることで実現している（Fig. 2a).デュアル モノマルチ（TC4538，Toshiba）を用い，1つ目に奇数 チャネル，2つ目には偶数チャネルの信号を加える.1 つ目のモノマルチの反転出力を用いて次のモノマルチ をトリガすると, 2 目のモノマルチは奇数チャネルを Hレベルの幅に, 偶数チャネルをLレベルの幅に乗せた PDM 出力を発生する (PDM, Fig. 2a). この PDM 信号で 1つ目のモノマルチをトリガして, 2つのチャネルの生 体信号を交互にPDM変調する自走マルチバイブレータ を構成している，さらに，2つ目のモノマルチの反転 出力でJ-K型フリップフロップ (TC74HC107, Toshiba) をトリガして, 多チャネルスイッチであるアナログマ ルチプレクサ (TC74HC4052, Toshiba) の選択入力を切 り替え, 次の周期ではチャネル 3 と 4 をPDM変調した 後, 再びチャネル 1 と 2 に戻る.

各チャネルにはオフセット電位 (チャネル $1,300 \mathrm{mV}$; チャネル2，3，4，690 mV）を付加し，PDM信号の H レベルとLレベルの持続時間を, 一定の幅（チャネル

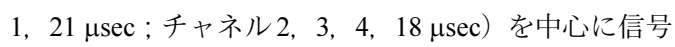

\title{
Recording of Biological Signals from Non-Tethered Crustaceans: Optical Telemetry System \\ Noriyuki HAMA ${ }^{1}$, Masakazu TAKAHATA ${ }^{1}$ and Yoshikazu TSUCHIDA ${ }^{2}$ \\ 'Division of Biological Sciences, Graduate School of Science, Hokkaido University \\ ${ }^{2}$ Reserch Institute for Electric Science, Hokkaido University
}




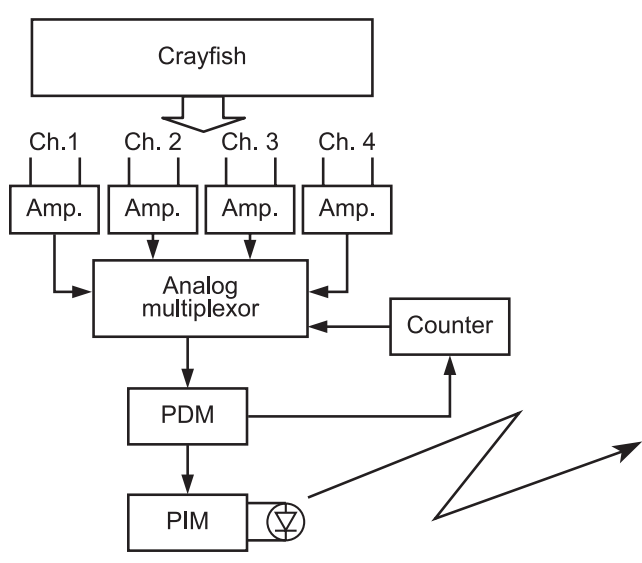

IRLED

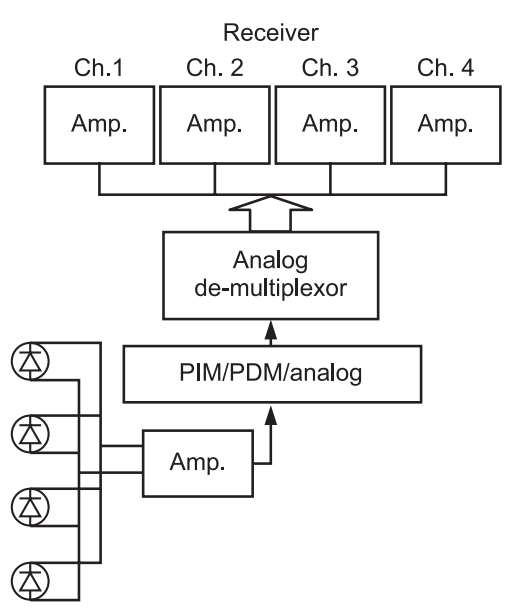

PIN-photodiode

Fig. 1 Schematic diagram of optical telemetry system. (回路図は電子ジャーナルの電子付録参照)

の振幅の高低に応じて短縮または延長する（PDM,

Fig. 2a). 約 $75 \mu \mathrm{sec}$ 毎に各チャネルをサンプリングす るため, サンプリング周波数は約 $14 \mathrm{kHz}$ を心に変動 する．後述するが，チャネル 1 に対応するパルスを他 のチャネルのパルスより長くすることによって， 復調 時にチャネル分離用の同期信号として用いる. 2 チャネ ルであれば, フリップフロップやマルチプレクサは不 要となり, 小型化が可能で, サンプリング周波数も約 $26.7 \mathrm{kHz}$ へと向上できる.

PDM信号からPIM信号への変換も同じデュアルモ， マルチ（74HC4538）を用いている. PDM信号の立ち上 がりエッジ (Lから Hレベルへの切り替わり)で $4 \mu \mathrm{sec}$ の幅の，逆に立ち下がり（Hから L レベルへの切り替 わり）で $2 \mu \sec$ の幅のパルスを発生させる. これで長
いパルスから短いパルスまでの時間の長さが生体信号 の振幅をコードするPIM変調が実現する (PIM, Fig. 2a). このPIM信号が赤外発光ダイオード (880 nm; CL-1CL3, Kodenshi Corp.) を駆動し, 赤外光パルスの間隔として 無線送信される. 送信器には変調回路用と発光ダイオー ド用にそれぞれ1個ずつリチウムボタン電池（3V; CR2032) を用いている. 電源を2つ用いるのは, 発光ダ イオード駆動時に生じる電圧低下による変調回路の誤 動作を防ぐためである.

受信器はFig. 1 に示すように, 波形整形回路, PIM/ $\mathrm{PDM}$ 復調器, $\mathrm{PDM} /$ アナログ復調器と各チャネルの増幅 器から構成されている. 一方向に配置した複数（4個） の PIN (p-intrinsic-n) フォトダイオード（S6967-01, Hamamatsuphotonics）を並列にして, 光パルスを受信す

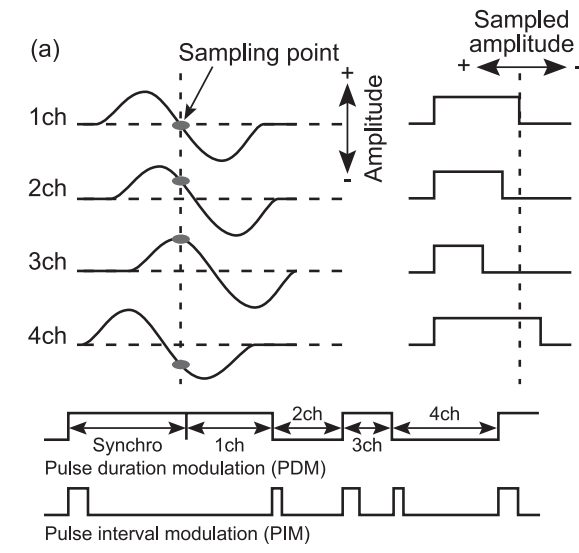

(b)
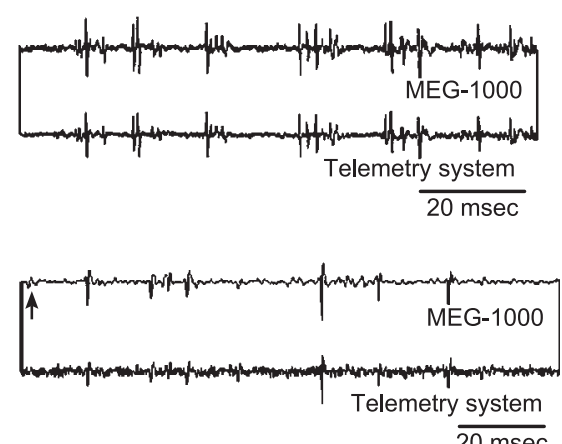

Fig. 2 (a) Outline of signal modulation. (b) Comparison of electromyographic activities (top) and neuronal activities (bottom) recorded by a wire-coupled conventional amplifier (MEG-1000) and by the optical telemetry system (Telemetry system). 
Table 1 Specification of optical telemetry system.

\begin{tabular}{llc}
\hline & \multicolumn{2}{c}{ Transmitter } \\
\cline { 2 - 3 } & \multicolumn{1}{c}{ Dual-channel } & \multicolumn{1}{c}{ Quad-channel } \\
\hline Main carrier: & $880 \mathrm{~nm}$ (infrared) & $880 \mathrm{~nm}$ (infrared) \\
Sampling frequency: & $26.7 \pm 3.5 \mathrm{kHz}$ & $14 \pm 2.5 \mathrm{kHz}$ \\
Total power consumption: & & \\
$\quad$ Circuit & $1.98 \mathrm{~mW}$ & $6.8 \mathrm{~mW}$ \\
$\quad$ LED & $27 \mathrm{~mW}$ & $36 \mathrm{~mW}$ \\
Supply voltage: & & \\
$\quad$ Circuit & $3 \mathrm{~V}$ & $3 \mathrm{~V}$ \\
$\quad$ LED & $3 \mathrm{~V}$ & $3 \mathrm{~V}$ \\
Battery retention time: & $6 \mathrm{hrs}$ & $4 \mathrm{hrs}$ \\
Frequency range of input signal: & $150 \mathrm{~Hz}-8.7 \mathrm{kHz}$ & $150 \mathrm{~Hz}-8.7 \mathrm{kHz}$ \\
Input impedance: & $1000 \mathrm{M} \Omega$ & $1000 \mathrm{M} \Omega$ \\
Gain of input amplifier: & $67.6 \mathrm{~dB}$ & $\pm 250 \mu \mathrm{dB}$ \\
Maxmum input voltage: & $\pm 250 \mu \mathrm{ch}), 67.4 \mathrm{~dB}(2,3,4 \mathrm{ch})$ \\
Transmitter package (with two batteries): & & \\
$\quad$ Volume & $4 \mathrm{~cm} 3$ & $10 \mathrm{~cm}{ }^{3}$ \\
$\quad$ Weight in air & $13 \mathrm{~g}$ & $16.2 \mathrm{~g}$ \\
Weight in water & $9 \mathrm{~g}$ & $6.2 \mathrm{~g}$ \\
\hline
\end{tabular}

る. 電流/電圧変換器 (LF6365, National Semiconductor) および増幅器 (LF357, National Semiconductor), 比較器 (LF311, National Semiconductor) を通して波形整形し, PIM信号を得る.このPIM信号を, デュアルD型フリッ プフロップ（TC4013， Toshiba）へ入力するとともに, $4 \mu \mathrm{sec}$ のパルスを検出し, フリップフロップをリセット することでPDM信号に復調する.PDM 信号からチャ ネル順に並んだランプ波の列を生成し，各パルスの持 続時間に比例した高さの信号を得る。このとき，チャ ネル 1 に対応する PDM信号のパルス幅は, 最も持続時 間が大きくなっている（Fig. 2a）ため，最も高いラン プ波としてチャネル 1 の信号（チャネル同期信号）が 検出できる. PIM信号をカウンタ（TC40163, Toshiba) のクロック信号，チャネル同期信号をリセット信号と してチャネル分離用のアナログデマルチプレクサ （TC4051，Toshiba）の出力を切り替える. PDM信号か ら生成したランプ波の頂上での振幅をこのアナログデ マルチプレクサによって各チャネルに分離する.

今回開発した光テレメトリシステムの特性はTable 1 に示すとおりで，筋電図記録や活動電位を記録するた めに十分な特性をもっていると考えられる．このこと をさらに検証するため, 通常の生体増幅器を用いた有 線記録によって得られる波形と, 光テレメトリシステ ムを用いて得られる波形の比較を行った。 これらの信 号をDATレコーダ (RD-135T, TEAC ; 周波数帯域 DC-
$10 \mathrm{kHz}$ ) で記録し, 実験終了後 A/D コンバータ (Power Lab, ADInstruments ; 周波数帯域 DC-2 kHz) に付属のソ フトウェア（Chartv4.2, ADInstruments）を用いて, コ ンピュータ (PowerMacintosh 7300) に取り込み, 解析 した. Fig. 2b は同じソースからの信号を有線と無線記 録で比較したものである。ザリガニ歩脚に一対の銀線 （直径 $125 \mu \mathrm{m}$ ）で作製された電極を挿入し, その出力を 生体増幅器と送信器に同時に接続している。筋電図記 録では，両者の記録間で大きな違いは見られない (Fig. 2b 上段). 一方, 神経活動の記録も同様に比較し た（Fig. 2b下段）。こちらは，笳電図記録とは異なり， 無線記録では有線記録に比べノイズが大きい事がわか る.そのため, 有線記録では確認できる小さなスパイ ク (図中矢印)が無線記録では確認が困難になっている.

\section{3. 光テレメトリシステムによる解析}

ザリガニ姿勢制御運動における，行動文脈依存的修 飾やその階層的制御機構の詳細については高畑による 本誌総説等を参考にされたい6),17)。これまでの研究は 腹部最終神経節における運動ニューロン等を中心に行 われてきた，我々のこれまでの研究では，平衡胞感覚 を出力伝達する経路を構成するニューロンの応答も運 動状態によって修飾されることが明らかになっている. 脳で統合処理された平衡胞感覚を体の各部に伝達する 平衡胞感覚性の下行性経路は複数のニューロンによっ 
(a)

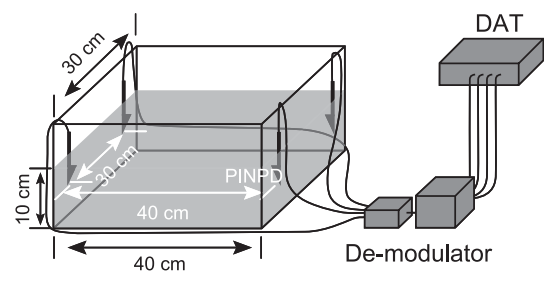

(b)

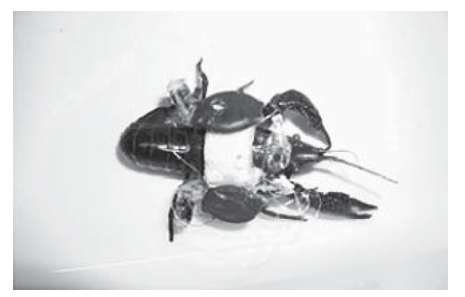

(c)

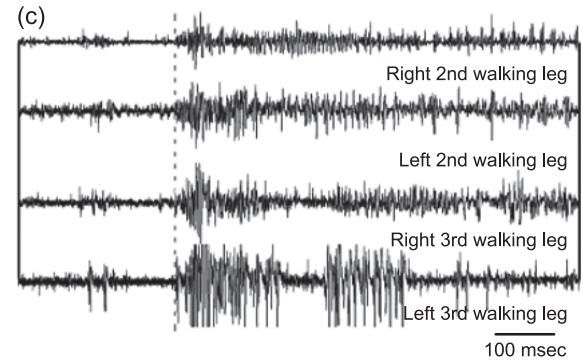

(d)

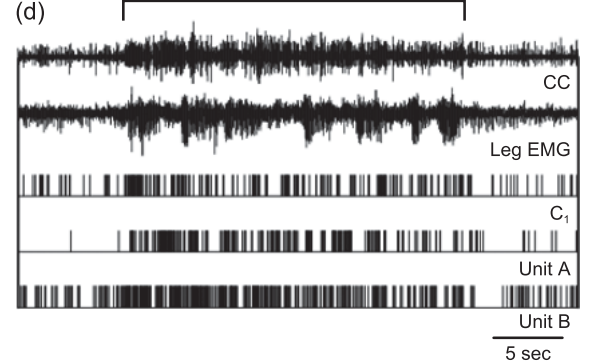

Fig. 3 Four PIN-photodiodes (PINPD) were placed at each corner of the experimental aquarium (40 cm in width $\times 30 \mathrm{~cm}$ in depth $\times 10 \mathrm{~cm}$ in height) (a). Electrodes for recording from the circumesophageal commissure and leg were connected with a dual-channel transmitter which was mounted on the cephalothorax of crayfish (b). EMG activities of four walking legs at the onset of walking increased simultaneously (c). The neuronal activities recorded from the circumesophageal commissure (CC) increased during walking (d). The walking behavior was indicated by rhythmic activities of the leg muscle (Leg EMG). (カラー図は電子ジャーナル参照)

て構成されている77,18). 今回はこれらのニューロンの うち細胞外記録法によって容易に同定できる $\mathrm{C}_{1}$ ニュー ロン活動の記録を行った ${ }^{19)}$. 細胞外記録用電極は左側 の囲食道縦連合に，筋電図記録用電極は第二歩脚長腕 節屈筋にそれぞれ設置した. 実験水槽（奥行き $40 \mathrm{~cm}$, 幅 $30 \mathrm{~cm}$, 高さ $15 \mathrm{~cm}$ ) には, 深さ $13 \mathrm{~cm}$ まで水を満た し，受信器である 4 個の PIN フォトダイオードを実験 水槽の各コーナーの底から $10 \mathrm{~cm}$ のころに内側に向 けて設置した (Fig. 3a). この水槽中に記録電極と2チャ ネル送信器を頭胸部 (cephalothorax)に取り付けたザリガ 二（Fig. 3b）を放し，自由に行動させた.

Fig. 3c は歩行運動開始時に記録された 4 本の歩脚筋電 図活動である. 歩行運動開始時（点線）に4 本の歩脚 すべてで同時に活動が上昇していることが確認できる.

Fig. 3d は歩行運動開始時における神経活動記録の一例 である. 細胞外記録（CC）から個々のスパイク活動を 抽出するには, Chart v4.2の Spike Histogram Extension を 用いている.この記録からは 5 種類のスパイク活動を 抽出することができたが, ここではそのうち $C_{1}$ ニュー ロンを含め活動の変化がみられた 3 種の下行性介在 ニューロンのスパイク活動を示してある $\left(\mathrm{C}_{1}\right.$, UnitA, Unit B, Fig. 3d). ここで示した下行性介在ニューロンは, い ずれも歩行運動中（図中の片ブラケット）は静止時に
比べ大きく活動が上昇していることが確認できる.し かしながらその上昇は一様ではなく, 歩行運動中大き く増減している. このことは, $C_{1}$ ニューロンの活動は 単純に感覚情報のみによって決定されているわけでは ないことを示唆する. 現在はビデオ撮影による行動解 析と組み合わせて, さまざまな行動下における修飾様 式を解析している.

\section{4. おわりに}

本テレメータの伝達距離は, 空気中であれば $1 \mathrm{~m}$ 以 上, 水中でも不安定にはなるが $50 \mathrm{~cm}$ 程度までは記録 可能である. 水の光吸収係数は波長が短くなるにした がって劇的に減少する16) ので, 用いる光の波長をより 短いものにすることで, 伝達距離がのびる. 今回我々 が $880 \mathrm{~nm}$ の赤外光を用いたのは, 甲殼類の視物質が $700 \mathrm{~nm}$ よ長い波長の光をほとんど受容しないためで ある ${ }^{20)}$. 周りに設置するPIN フォトダイオードの数を さらに増やすことによっても距離の延長が可能である.

送信器の重量については, 今回は水中で使用したた め, それほど大きな問題とはならなかった，実際，水 中での重量はザリガニの重量の約 20\%であり, この程 度の負荷であれば歩行の妨げにならないと考えられる. しかしながら, より小型の魚類などに使用するには, 軽 
量化しなければならない。その場合，もっとも簡便な のは電池の小型化である。今回我々が用いたリチウム ボタン電池 (CR2032) は市販の電池の中でも大型のも ので, 送信器の重量の大半は電池の重量となっている. より小型の電池を用いることで，手軽に軽量化が可能 である.しかし，小型の電池を用いると，より頻繁な 電池の交換が必要になる。

現状では, アメリカザリガニのような中型の甲殼類 などであれば本システムを用いることは容易である.し かしながら，小型の魚類や行動範囲の広い動物などに 本システムを導入する場合は上記のような改善をほど こさなければならない。本システムが広範囲に用いら れることを期待する.

\section{文 献}

1) Horak, F. B. and Macpherson, J. M. (1996) Handbook of Physiology, 255-292, Oxford University Press.

2) Deliagina, T. G., Orlovsky, G. N., Selverston, A. I. and Arshavsky, Y. I. (1999) J. Neurophysiol. 82, 687-699.

3) Davis, W. J., Mpitsos, G. J. and Pinneo, J. M. (1974) J. Comp. Physiol. 90, 207-224.

4) Everett, R. A., Ostfeld, R. S. and Davis, W. J. (1982) Z Tierphyschol. 59, 109-126.

5) Deliagina, T. G., Zelein, P., Fagerstedt P., Grillner S. and Orlovsky G. N. (2000) J. Neurophysiol. 83, 853-863.
6) Murayama, M. and Takahata, M. (1992) J. Comp. Physiol. A 170, 463-477.

7) Hama, N. and Takahata, M. (2003) J. Comp. Physiol. A 189, 877-888.

8) Albright, C. D., MacGarry, W. P., Ott, O. J. and Runyan, R. A. (1967) Handbook of Telemetry and Remote Control, 16 (Chapter 6), Magrew-Hill.

9) Mackey, R. S. (1970) Bio-telemetry.

10) Fisher, H., Kauts, H. and Kutsch, W. J. (1996) Neurosci. Methods 64, 39-45.

11) Ando, N., Shimoyama, I. and Kanzaki, R. (2002) J. Neurosci. Methods 115, 181-187.

12) Stasko, A. B. and Pincock D. G. (1977) J. Fish Res. Bd. Can. 34, 1261-1285.

13) Winter, J. D., Ross, M. J. and Kuechle, V. B. (1984) Biotelemetry VIII, 391-395.

14) Sisak, M. M. and Lotimaer, J. S. (1984) Hydrobiologia 374/372, 53-59.

15) Kudo, Y., Satou, M., Kitamura, S., Iwata, M. and Takeuchi, Y. (1999) Fron. Med. Biol. Eng. 9, 285-294.

16) Hale, G. M. and Querry, M. R. (1973) Appl. Opt. 12, 555563.

17）高畑雅一 (2000) 生物物理 40, 239-243.

18) Nakagawa, H. and Hisada, M. (1989) Cell Tissue Res. 255, 539-551.

19) Takahata M. and Hisada, M. (1982) J. Comp. Physiol. 149, 287-300.

20) Goldsmith, T. H. (1972) Handbook of Sensory Physiology VII/1, 685-719. 


\section{濱 徳行（はま のりゆき）}

北海道大学大学院理学研究科生物科学専攻博士後期課程 3 年 連絡先： ₹ 060-0810 札幌市北区北 10 条西 8 丁目

E-mail: hnori@sci.hokudai.ac.jp

高畑雅一（たかはた まさかず）

北海道大学大学院理学研究科生物科学専攻教授

連絡先：干060-0810 札幌市北区北 10 条西 8 丁目

E-mail: takahata@sci.hokudai.ac.jp

土田義和（つちだ よしかず）

北海道大学電子科学研究所技術部職員

連絡先: $=060-0810$ 札幌市北区北 12 条西 6 丁目

E-mail: tsuchida@ncp8.es.hokudai.ac.jp 